\title{
Future mobility without internal combustion engines and fuels?
}

For many decades to come, and in the foreseeable future, internal combustion engines - in many cases with electric motors - will be with us, just like the liquid fuels they require. The importance of crude oil will decline, as these fuels will be increasingly produced on a synthetic basis without $\mathrm{CO}$, emissions. The answers to the question "'Future Mobility without Internal Combustion Engines and Fuels? " are "no" in both cases. Purely battery-electric mobility will be applied in the future only in specific areas. Fuel-cell vehicles will hardly be used because of the extreme infrastructure investment costs. In contrast, liquid fuels will ensure the future of mobility. In this scenario, energy such as solar or wind energy will be generated without $\mathrm{CO}_{2}$ emissions.

Key words: transport, combustion engines, engine fuels, alternative powertrains, alternative fuels

\section{Czy w przyszlości transport będzie mógl funkcjonować bez silników spalinowych i paliw?}

\begin{abstract}
Silniki spalinowe funkcjonuja jako źródła napędu pojazdów już ponad 100 lat $i$ w dającej się przewidzieć przyszłości wciąz będa powszechnie stosowane, podobnie jak paliwa plynne potrzebne do ich zasilania. Znaczenie ropy naftowej będzie jednak powoli malało w miare wzrostu skali produkcji paliw syntetycznych, w procesach zapewniajacych mała emisję $\mathrm{CO}_{2}$. Odpowiedź na pytanie: czy transport w przyszłości będzie odbywać się bez silników spalinowych i paliw brzmi: nie. Napęd elektryczny stosowany będzie tylko na wybranych obszarach. Pojazdy wykorzystujace ogniwa paliwowe nigdy nie osiagna większej popularności ze względu na wysokie koszty budowy niezbędnej infrastruktury. Tylko paliwa płynne będa w stanie zaspokoić przyszłościowe potrzeby transportu. Do ich wytworzenia wykorzystywana będzie jednak energia ze źródeł o zerowej emisji $\mathrm{CO}_{2}$, jak na przyktad baterie słoneczne, czy farmy wiatrowe.
\end{abstract}

Słowa kluczowe: transport, silnik spalinowy, paliwa silnikowe, napędy alternatywne, paliwa alternatywne

\section{Why does the question arise?}

We have a mobility system based on internal combustion engines or turbines as drive units for vehicles, boats and aircraft. This system functions excellently both in terms of technology and fuel supply. Why then should we ask this question?

There are two reasons:

First: the availability of crude oil, at least in the quantities consumed at present, is limited, and

Second: warnings have repeatedly been voiced by the majority of climatologists that carbon dioxide $\left(\mathrm{CO}_{2}\right)$, released during the combustion of crude oil derivatives would bring about a climate change leading to global warming.

Not all climate scientists share this view, but the majority believe in this prediction - and what is more important, politicians in almost all countries have taken over this theory and passed legislation imposing limits on $\mathrm{CO}_{2}$ emissions. Therefore, we have grounds for supposing that in the future emissions caused by mobility will have to be reduced and we will have to consume, at least to some extent, more energy from sources other than oil.

With a great feeling of euphoria, a lot of propaganda is currently being created for the electric drive. The media and politicians are out-doing each other in predicting the dawning of the electric era of mobility.

\section{E-mobility is nothing new}

As early as 1899 Ferdinand Porsche designed a car which was driven by means of a battery. The so-called LohnerPorsche that was equipped with a wheel-hub motor (Fig. 1) was presented at the Paris World Exhibition in 1900.

\section{Dlaczego pojawia się zawarte w tytule pytanie}

W pojazdach, łodziach i statkach powietrznych jako jednostki napędowe wykorzystuje się najczęściej silniki lub turbiny spalinowe. W zakresie użytych technologii oraz zastosowanych paliw układy te funkcjonują niezawodnie. Skąd więc bierze się pytanie dotyczące przyszłości silników spalinowych i paliw płynnych?

Są dwa powody:

Pierwszy: zasoby ropy naftowej, przy założeniu obecnego poziomu jej zużycia, są ograniczone,

Drugi: wielokrotne ostrzeżenia większości klimatologów mówią, że dwutlenek węgla $\left(\mathrm{CO}_{2}\right)$ emitowany podczas spalania paliw naftowych powoduje zmiany klimatu prowadzące do globalnego ocieplenia. Nie wszyscy klimatolodzy podzielają tę opinię, jednakże większość z nich wierzy w te prognozy - co ważniejsze, politycy w niemalże wszystkich krajach również jej ulegają, uchwalając ustawy limitujące emisję $\mathrm{CO}_{2}$. Dlatego istnieją podstawy, by przypuszczać, że emisja pojazdów w przyszłości będzie musiała być zredukowana przy jednoczesnym zwiększeniu zużycia energii ze źródeł innych niż ropa naftowa. Należy przy tym podkreślić, że napędy elektryczne przyjmowane $\mathrm{z}$ dużą euforią stanowią jedynie element swoistej propagandy, pozwalającej mediom i politykom prześcigać się $\mathrm{w}$ przewidywaniu nadejścia ery transportu elektrycznego.

\section{E-mobilność - nic nowego}

W roku 1899 Ferdinand Porsche skonstruował samochód, którego napęd realizowany był z wykorzystaniem akumulatorów elektrycznych. Samochód Lohner Porsche zaprezentowany na Wystawie Światowej w Paryżu w 1900 
This vehicle, which reached a maximum speed of $50 \mathrm{~km} /$ hour and had a range of $50 \mathrm{~km}$, had a battery that weighed $410 \mathrm{~kg}$. In the same year, Porsche developed a car with wheel-hub motors on the rear wheels in addition to its front drive. Thus, the first four-wheel drive motor vehicle was born. The weight of the battery was increased from $410 \mathrm{~kg}$ to $1,800 \mathrm{~kg}$ with a view to extending the range. Even these larger batteries did not permit a satisfactory extension of the range of these vehicles. Therefore, Porsche designed the first hybrid electric vehicle, the so-called Mixte car in which the battery was charged with the aid of an internal combustion engine.

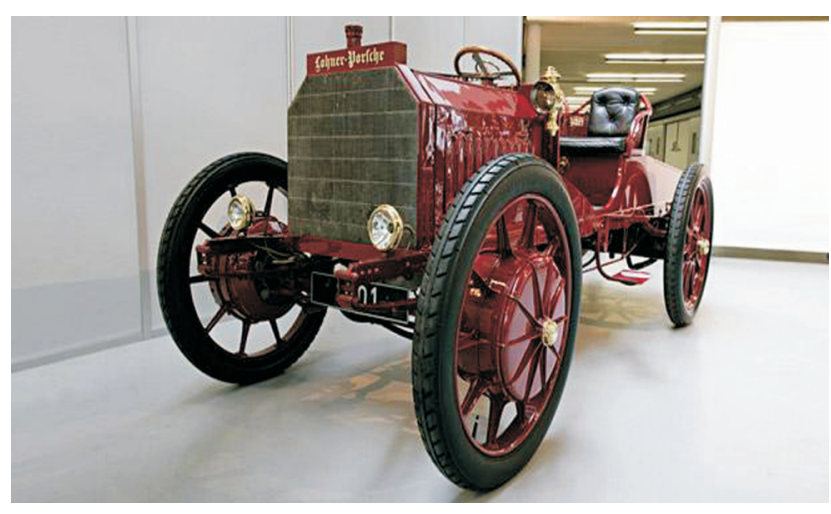

Fig. 1. Lohner Porsche HEV with wheel-hub motor drive [16]

Rys. 1. Lohner Porsche z umieszczonymi w piastach kót silnikami elektrycznymi [16]

These vehicles were so expensive that only the wellto-do were able to buy them. Additionally, owing to their limited range, they were not sold in large numbers. Since that time, attempts have repeatedly been made to launch electric vehicles in the market. Two examples of these efforts were the cars introduced by Volkswagen and MAGNA:

- Golf 1 Electric BEV 1976

- Typ 2 Electric BEV 1977

- Jetta Citystromer BEV 1985

- Golf 2 Citystromer BEV 1991

- ElectroVan BEV 1992

- Golf 3 Citystromer BEV 1995

Figure 2 gives a survey of the development efforts made by the MAGNA-Group and shows that the supplier industry was also involved in the development of such vehicles to a great extent.

The current argument that the electric cars of today would be much better, if more development efforts had gone into them is simply wrong. In addition, large-scale tests subsidized with government funds, such as the test on Ruegen Island in the early roku wyposażony był w silniki umieszczone w piastach kół (rys. 1). Pojazd umożliwiał rozwinięcie prędkości maksymalnej $50 \mathrm{~km} / \mathrm{h}$ i pokonanie dystansu $50 \mathrm{~km}$. Masa akumulatorów wynosiła $410 \mathrm{~kg}$. W tym samym roku Porsche rozwinął konstrukcję samochodu, stosując silniki umieszczone w piastach tylnych kół, jako uzupełnienie stosowanego już przedniego napędu. Tak narodził się pierwszy pojazd z napędem na cztery koła. Masa akumulatorów wzrosła z $410 \mathrm{~kg}$ do $1800 \mathrm{~kg}$, zapewniając przy tym zwiększenie zasięgu pojazdu. Zwiększona pojemność akumulatorów wciąż nie zapewniała jednak osiągnięcia satysfakcjonującego zasięgu. W związku z tym Porsche skonstruował pierwszy hybrydowy pojazd nazwany Mixte, w którym akumulatory były doładowywane za pomocą silnika spalinowego.

Pojazd ten był jednak drogi i tylko bardzo zamożne osoby mogły sobie pozwolić na jego zakup. Dodatkową przyczyną małej sprzedaży był niewielki zasięg samochodu. W późniejszych czasach wielokrotnie pojawiały się próby wprowadzenia pojazdów elektrycznych na rynek. Przykładami były pojazdy firm Volkswagen oraz MAGNA:

- Golf 1 Electric BEV 1976

- Typ 2 Electric BEV 1977

- Jetta Citystromer BEV 1985

- Golf 2 Citystromer BEV 1991

- ElectroVan BEV 1992

- Golf 3 Citystromer BEV 1995.

Na rysunku 2 przedstawiono przegląd najważniejszych wydarzeń związanych z rozwojem pojazdów elektrycznych przez Grupę MAGNA. Istotną rolę w postępie odegrały duże firmy motoryzacyjne, będące odbiorcami wytwarzanych rozwiązań.

Często pojawiające się obecnie stwierdzenie, że współczesne elektryczne pojazdy byłyby znacznie bardziej

\section{Electric - Drive / Hybrid Integration \\ II MAGNA E-CAR SYSTEMS}

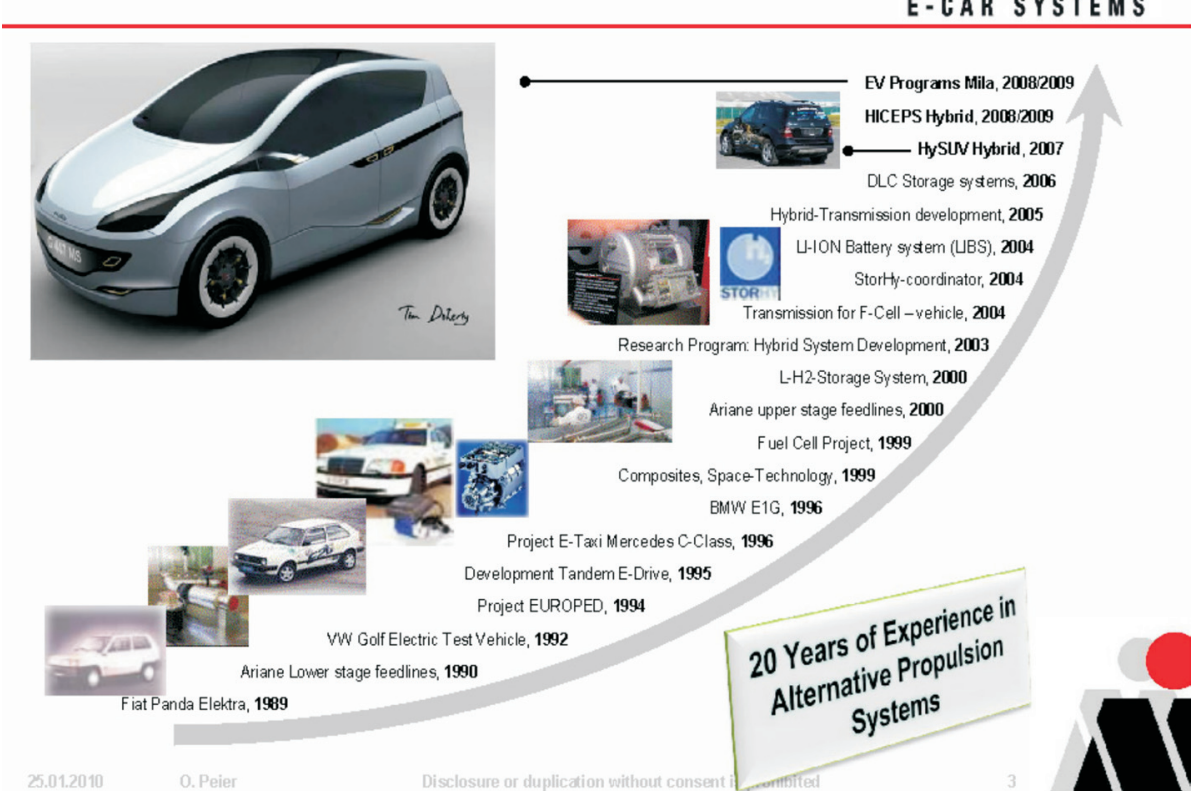

Fig. 2. Electric Drive / Hybrid Integration

Rys. 2. Chronologia rozwoju napędu elektrycznego i hybrydowego [16] 
nineties, have failed. BMW, Mercedes, VW, Opel and other vehicle manufacturers joined forces to test various vehicles, charging systems, and batteries. The overall outcome was negative. Ranges, costs and environmental impact assessments were unsatisfactory.

In part three of the paper I will come back to this issue and give you an updated survey by comparing the systems internal combustion engines/fuels with electric motors/batteries and their infrastructures.

\section{Comparison of the systems: internal combustion engines/fuels and electric motors/ batteries, including infrastructures}

This study [1] analyzed the advantages and drawbacks of 5 battery-electric vehicles and a modern conventional diesel passenger car. In the study, not only were real-life driving conditions taken into account, but also energy availability in the forms of electric power and diesel fuel. In addition, the attainable ranges and energy costs were calculated. For this purpose, the Department for Vehicle Propulsion Systems and Automotive Engineering of Vienna University of Technology analyzed five of the current battery-electric passenger cars and one state-of-the-art diesel-engine powered passenger car. These were the following:

- Mitsubishi i-MiEV

- Mercedes Benz A-Klasse E-Cell

- Smart Fortwo Electric Drive

- Nissan Leaf

- Citroën Berlingo

- Volkswagen Polo BlueMotion (diesel passenger car).

The fuel consumption and greenhouse gas emissions of the diesel-engine car as well as the energy flows of the electric car were studied using an air-conditioned roller dynamometer. By determining the tractive resistance values for the individual cars, by varying the ambient temperature (heating/cooling of the interior) and by driving in different modes (stop-and-go, urban, interurban and driving on a highway) with varying inclinations of the road $(-2 \%$, $0 \%$ and $+2 \%$ ) it was possible to calculate the near real-life energy required by each car. Alongside these examinations of vehicle parameters, the energy requirements and greenhouse gas emissions resulting from energy generation (production of diesel fuel) were also taken into account on the basis of findings described in the relevant literature.

In view of the variations in average temperatures and the divergent production paths of electric power and diesel fuel, the annual energy consumption and the resulting annual greenhouse gas emissions were calculated separately for both Austria and the European Union. Furthermore, a distinction was made between urban and long-distance drivers.

\section{Energy benefit}

Table 1 illustrates the average energy requirement for the pure driving mode. This study took into account the energy required for driving on a road with an average inclination, for air-conditioning of the vehicle interior (heating or cooling depending on the average monthly ambient temperature) and for the charging and discharging losses of the high-voltage zaawansowane, gdyby kładziono większy nacisk na ich rozwój, jest błędne. Dodatkowo prowadzone na szeroką skalę, dotowane funduszami rządowymi, badania - takie jak choćby te prowadzone na początku lat dziewięćdziesiątych XX w. w niemieckiej Rugii - nie przyniosły spodziewanych rezultatów. Firmy, takie jak BMW, Mercedes, VW i Opel zjednoczyły wówczas swoje siły, skupiając się na rozwoju m.in. systemów ładowania i akumulatorów. Ostateczny wynik był jednak niezadowalający. Zasięg pojazdów, przewidywane koszty wytwarzania oraz ogólna ocena wpływu na środowisko naturalne nie były możliwe do zaakceptowania. W następnym rozdziale będzie szerzej przedstawiony ten temat - porównane będą silniki spalinowe i stosowane $\mathrm{w}$ nich paliwa $\mathrm{z}$ silnikami elektrycznymi/akumulatorami i niezbędną do ich działania infrastrukturą.

\section{Porównanie rozwiązań: silniki spalinowe/ paliwa oraz silniki elektryczne/akumulatory z uwzględnieniem infrastruktury}

W pracy [1] dokonano analizy porównawczej zalet i wad pięciu pojazdów elektrycznych na tle nowoczesnego konwencjonalnego samochodu osobowego z silnikiem ZS. W ocenie tej, poza porównaniem właściwości pojazdów w warunkach rzeczywistego ruchu drogowego, wzięto również pod uwagę dostępność energii elektrycznej i oleju napędowego. Określono ponadto możliwy do pokonania przez pojazdy dystans, jak również koszt zużytej energii. Omawianą analizę przeprowadzono na Wydziale Techniki Samochodowej i Układów Napędowych Pojazdów Uniwersytetu Technicznego w Wiedniu. Zestawiono pięć samochodów osobowych $z$ napędem elektrycznym i jeden pojazd reprezentujący aktualny stan rozwoju napędzany silnikiem ZS. Były to:

- Mitsubishi i-MiEV

- Mercedes Benz A-Klasse E-Cell

- Smart Fortwo Electric Drive

- Nissan Leaf

- Citroën Berlingo

- Volkswagen Polo BlueMotion (samochód osobowy z silnikiem ZS).

Zużycie paliwa oraz emisja gazów cieplarnianych w samochodzie wyposażonym w silnik ZS, jak również przepływ energii $w$ samochodzie $z$ napędem elektrycznym mierzone były na stabilizowanej cieplnie hamowni podwoziowej. Przez określenie wartości oporów ruchu pojazdów, przy uwzględnieniu temperatury otoczenia oraz jazdy w różnych trybach (stop and go, tryb miejski, pozamiejski, autostradowy), przy zmiennym nachyleniu drogi $(-2 \%, 0 \% \mathrm{i}+2 \%)$ możliwe było obliczenie dla badanych pojazdów, zbliżonego do warunków rzeczywistego ruchu, zapotrzebowania na energię. Poza wymienionymi parametrami na podstawie analizy literaturowej brano pod uwagę zapotrzebowanie na energię oraz emisję gazów cieplarnianych wynikającą $\mathrm{z}$ procesu produkcji energii (produkcja oleju napędowego).

Roczne zużycie energii oraz wynikowa roczna emisja gazów cieplarnianych obliczono oddzielnie dla Austrii i reszty Unii Europejskiej - wynikało to z różnic w średnich tempe- 
battery. The energy required for driving an electric passenger car in a European city corresponds to $53 \%$ of that of a diesel-engine powered passenger car. This analysis demonstrates the energy benefit of battery-electric vehicles during pure driving.

However, if the energy required for power generation here in Europe is taken into consideration as well, in the urban driving mode, electric passenger cars consume $33 \%$ more energy than diesel-engine powered cars. As can be seen from Table 2, the energy benefit shrinks drastically if energy generation is also taken into account. In long-distance driving, this energy benefit turns into a disadvantage, as electric motor-driven passenger cars consume $43 \%$ more energy in Europe than diesel-engine powered passenger cars.

Due to the lack of sufficient data, the production of electric passenger cars, which at present is still energy-intensive raturach oraz różnych metod produkcji energii elektrycznej i oleju napędowego. Dodatkowe rozróżnienie wykonano dla jazdy w cyklu miejskim i pozamiejskim.

\section{Korzyści energetyczne}

W tabeli 1 przedstawiono średnie zapotrzebowanie na energię w trybie jazdy. Dane te uwzględniają jazdę przy średnim nachyleniu terenu, z użyciem klimatyzacji (ogrzewanie lub chłodzenie w zależności od średniej temperatury otoczenia $\mathrm{w}$ danym miesiącu) oraz straty ładowania i rozładowania wysokonapięciowych akumulatorów. Zapotrzebowanie na energię pojazdów elektrycznych w czasie jazdy w warunkach typowych dla miast europejskich stanowi $53 \%$ zapotrzebowania wymaganego dla tych samych warunków $\mathrm{w}$ odniesieniu do pojazdu z silnikiem ZS. Zestawienie to uwidacznia korzyści energetyczne dla pojazdów z napędem elektrycznym.

Table 1. Average energy required for driving (excluding energy supply)

Tabela 1. Średnie zapotrzebowanie na energię w zależności od trybu jazdy (z pominięciem procesu produkcji energii) [1]

\begin{tabular}{|l|l|c|c|c|}
\hline Energy required/zapotrzebowanie na energie [kWh/100 km] & \multicolumn{2}{|c|}{$\begin{array}{c}\text { Urban driver/cykl miejski } \\
\text { Lozamiejski }\end{array}$} \\
\hline Austria & $\begin{array}{l}\text { diesel passenger car/samochody } \\
\text { z silnikami ZS }\end{array}$ & 42.9 & $100 \%$ & 42.1 \\
\cline { 2 - 5 } & $\begin{array}{l}\text { electric motor car/samochody } \\
\text { z napędem elektrycznym }\end{array}$ & 24.5 & $\mathbf{5 7 \%}$ & 25.5 \\
\hline European Union/Unia Europejska & $\begin{array}{l}\text { diesel passenger car/samochody } \\
\text { z silnikami ZS }\end{array}$ & 42.8 & $100 \%$ & 42.0 \\
\cline { 2 - 5 } & $\begin{array}{l}\text { electric motor car/samochody } \\
\text { z napędem elektrycznym }\end{array}$ & 22.8 & $\mathbf{5 3} \%$ & 24.2 \\
\hline
\end{tabular}

Table 2. Average energy required for driving (including energy generation)

Tabela 2. Średnie zapotrzebowanie na energię w zależności od trybu jazdy (z uwzględnieniem procesu produkcji energii) [1]

\begin{tabular}{|c|c|c|c|c|c|}
\hline \multicolumn{2}{|c|}{$\begin{array}{l}\text { Energy required/zapotrzebowanie na energie } \\
\qquad[\mathrm{kWh} / 100 \mathrm{~km}]\end{array}$} & \multicolumn{2}{|c|}{ Urban driver/ cykl miejski } & \multicolumn{2}{|c|}{ Long distance driver/cykl pozamiejski } \\
\hline \multirow[t]{2}{*}{ Austria } & $\begin{array}{c}\text { diesel passenger car/samochody } \\
\text { z silnikami } Z S\end{array}$ & 51.1 & $100 \%$ & 50.2 & $100 \%$ \\
\hline & $\begin{array}{l}\text { electric motor car/pojazdy } \\
\text { elektryczne }\end{array}$ & 37.9 & $74 \%$ & 39.5 & $79 \%$ \\
\hline
\end{tabular}

(on account of the high-voltage batteries), has not been taken into account in this calculation. However, the energy required for the production of a high-voltage battery can, in all probability, be assumed to correspond to approximately $13 \%$ of the annual energy consumption of an electric passenger car $[3,4]$.

\section{Climate benefit}

The greenhouse gas emissions (considered as $\mathrm{CO}_{2}$ equivalent) resulting from driving and energy generation for electric passenger cars in the urban driving mode amount to $38 \%$ of that of diesel cars because of the high percentage of renewable energy used for electricity generation in Austria. At the European level, this benefit corresponds to $83 \%$ and thus is significantly smaller. Table 3 gives a survey of the relevant figures:
Biorąc pod uwagę konieczność wyprodukowania energii elektrycznej (tab. 2), w realiach UE dla samochodów elektrycznych w cyklu miejskim stwierdzono zwiększone o $33 \%$ zużycie energii w stosunku do samochodów z silnikami ZS. Jeśli zostaną wzięte pod uwagę procesy produkcji energii, to na podstawie analizy danych zawartych w tabeli 2 można zauważyć, że zysk energetyczny znacznie maleje. W cyklu pozamiejskim odnośnie do danych dla Unii Europejskiej dla elektrycznie napędzanych pojazdów zysk energetyczny jest również ujemny w porównaniu do samochodów z silnikami ZS (różnica $43 \%$ ).

W powyższych szacunkach ze względu na brak wystarczających danych nie wzięto pod uwagę zużycia energii wynikającego z produkcji samochodów z napędem elektrycznym. Czynnik ten jest istotny choćby z uwagi na 


\section{Range and convenience}

The ranges indicated in Table 4 can be attained with an average driving style and a small inclination of the road. When the air-conditioning system is activated at an ambient temperature of $+30{ }^{\circ} \mathrm{C}$, the range reduction averages $14 \%$. When the car interior is heated at an ambient temperature of $0{ }^{\circ} \mathrm{C}$, the average range reduction amounts to $27 \%$.

\section{Energy costs}

Due to the current taxes and levies on electric power and diesel fuel, the energy costs of electric cars for final consumers are lower than those of diesel-engine powered passenger cars. If these taxes and levies are not taken into account, the costs of electric cars in the urban driving cycle are higher than those of diesel-engine powered cars. In the medium term, wykorzystywane w tych pojazdach akumulatory. W pracach $[3,4]$ stwierdzono jednak, że energia potrzebna do produkcji wysokonapięciowych akumulatorów wynosi około $13 \%$ rocznego zużycia energii przez typowy samochód osobowy z napędem elektrycznym.

\section{Korzyści środowiskowe}

W odniesieniu do Austrii emisja gazów cieplarnianych uwzględniająca proces produkcji energii elektrycznej oraz jazdę pojazdów z napędem elektrycznym poruszających się w cyklu miejskim wynosi około $38 \%$ wartości przyjętej dla samochodów z silnikami ZS. Ta stosunkowo niska wartość wynika przede wszystkim z użycia głównie energii odnawialnej. Dla całej Unii Europejskiej zysk ten jest znacznie niższy (tab. 3).

Table 3. Average greenhouse gas emissions from normal driving (including energy generation)

Tabela 3. Średnia emisja gazów cieplarnianych dla cyklu miejskiego i pozamiejskiego (z uwzględnieniem procesu produkcji energii) [1]

\begin{tabular}{|c|c|c|c|c|c|}
\hline $\begin{array}{l}\text { Greenhouse gas emissions/emisja } \\
\text { gazów cieplarnianych }\left[\mathrm{g} \mathrm{CO}_{2 \mathrm{e}} / \mathrm{km}\right]\end{array}$ & Urban driver/cykl miejski & \multicolumn{4}{|c|}{ Long distance driver/cykl pozamiejski } \\
\hline \multirow[t]{2}{*}{ Austria } & $\begin{array}{c}\text { diesel passenger car/samochody } \\
\text { z silnikami ZS }\end{array}$ & 128 & $100 \%$ & 126 & $100 \%$ \\
\hline & $\begin{array}{l}\text { electric motor car/samochody } \\
\text { z napędem elektrycznym }\end{array}$ & 48 & $38 \%$ & 50 & $40 \%$ \\
\hline \multirow[t]{3}{*}{ European Union/Unia Europejska } & $\begin{array}{c}\text { diesel passenger car/samochody } \\
\text { z silnikami ZS }\end{array}$ & 132 & $100 \%$ & 129 & $100 \%$ \\
\hline & $\begin{array}{c}\text { electric motor car/samochody } \\
\text { z napędem elektrycznym }\end{array}$ & 109 & $83 \%$ & 116 & $90 \%$ \\
\hline & $\begin{array}{c}\text { electric motor car/samochody } \\
\text { z napędem elektrycznym }\end{array}$ & 37.9 & $74 \%$ & 39.5 & $79 \%$ \\
\hline \multirow[t]{2}{*}{ European Union/Unia Europejska } & $\begin{array}{c}\text { diesel passenger car/samochody } \\
\text { z silnikami ZS }\end{array}$ & 48.8 & $100 \%$ & 47.5 & $100 \%$ \\
\hline & $\begin{array}{l}\text { electric motor car/samochody } \\
\text { z napędem elektrycznym }\end{array}$ & 64.2 & $133 \%$ & 68.1 & $143 \%$ \\
\hline
\end{tabular}

the purchase prices for electric passenger cars will continue to exceed the additional costs customers are prepared to pay. In the long run, mass produced electric cars will cost more than $€ 6.000$ more than comparable conventional cars [5]. At present, the prices for the commercially available electric passenger cars are approximately twice as high as those for comparable conventional cars.

What are the expectations of consumers when they buy a battery-driven passenger car?

\section{Komfort termiczny podróżowania a zasięg pojazdu}

Zasięgi pojazdów osiągane przy normalnym stylu jazdy po drogach z niewielkim nachyleniem przedstawiono w tabeli 4. Przy temperaturze otoczenia wynoszaceej $+30^{\circ} \mathrm{C}$ w chwili aktywowania układu klimatyzacji zasięg pojazdów elektrycznych maleje o około $14 \%$. W przypadku ogrzewania wnętrza pojazdu przy temperaturze otoczenia równej $0{ }^{\circ} \mathrm{C}$ zasięg maleje o około $27 \%$.

Table 4. Attainable ranges

Tabela 4. Zestawienie zasięgów analizowanych pojazdów [1]

\begin{tabular}{|c|c|c|c|}
\hline \multirow{2}{*}{$\begin{array}{l}\text { Range less reserve range } 25 \mathrm{~km} / \text { zasięg po- } \\
\text { jazdu (bez } 25 \mathrm{~km} \text { zasięgu rezerwowego) }\end{array}$} & \multicolumn{3}{|c|}{ Ambient temperature/temperatura otoczenia } \\
\hline & $\begin{array}{c}20{ }^{\circ} \mathrm{C} \text { without heating and air-con- } \\
\text { ditioning/bez ogrzewania } \\
\text { i klimatyzacji }\end{array}$ & $\begin{array}{c}0{ }^{\circ} \mathrm{C} \text { including heating } / z \text { ogrze- } \\
\text { waniem }\end{array}$ & $\begin{array}{l}-10{ }^{\circ} \mathrm{C} \text { including } \\
\text { heating/z ogrzewaniem }\end{array}$ \\
\hline Mitsubishi i-MiEV & $83 \mathrm{~km}$ & $48 \mathrm{~km}$ & $41 \mathrm{~km}$ \\
\hline Mercedes Benz A-Klasse E-Cell & $150 \mathrm{~km}$ & $101 \mathrm{~km}$ & $85 \mathrm{~km}$ \\
\hline Smart Fortwo Electric Drive & $100 \mathrm{~km}$ & $64 \mathrm{~km}$ & $52 \mathrm{~km}$ \\
\hline Nissan Leaf & $76 \mathrm{~km}$ & $53 \mathrm{~km}$ & $41 \mathrm{~km}$ \\
\hline Citroën Berlingo & $60 \mathrm{~km}$ & $54 \mathrm{~km}$ & $51 \mathrm{~km}$ \\
\hline Volkswagen Polo BlueMotion & $1090 \mathrm{~km}$ & $1036 \mathrm{~km}$ & $989 \mathrm{~km}$ \\
\hline
\end{tabular}


1. In the medium term, the purchase prices will continue to exceed the additional costs accepted by customers. At present, the prices of electric cars are twice as high as those of conventional cars.

2. The energy costs for the operation of electric cars are lower than those of diesel-engine powered cars because of the current taxes and levies on electric power and diesel fuel.

3. Compared to conventional vehicles, the range of today's commercially available electric passenger cars is very limited and depends on the ambient temperature. This disadvantage is not expected to be overcome in the long term.

4. Charging and Convenience

An electric plug located at a close distance from the car park is indispensable for the operation and/or charging of the batteries of electric cars. The battery charging process requires additional technical manipulation (plugging in and unplugging).

5. Effect on the climate and energy requirement

If an electric passenger car is operated in a country in which a high percentage of the generated energy comes from renewable sources (i.e. Austria, for example), electric cars reduce both the energy consumption and greenhouse gas emissions in this country. If we look at the situation in the European Union as a whole, benefits are hardly visible. In countries in which only a small portion of energy is generated from renewable sources, in which low

average temperatures prevail or long distances are driven in the medium speed range, diesel-engine powered cars offer the advantage of lower energy consumption and/ or lower greenhouse gas emissions. Finally, if we take a look at the energy density of the different sources, Figure 3 reveals drastic differences. In terms of both gravimetric energy density and volumetric energy density, more than one power of ten is missing.

\section{Comparison of infrastructures}

In this context, infrastructure means, first and foremost, the availability of stations for supplying energy, i.e. filling stations for liquid or gaseous fuels (CNG, LPG) and stations

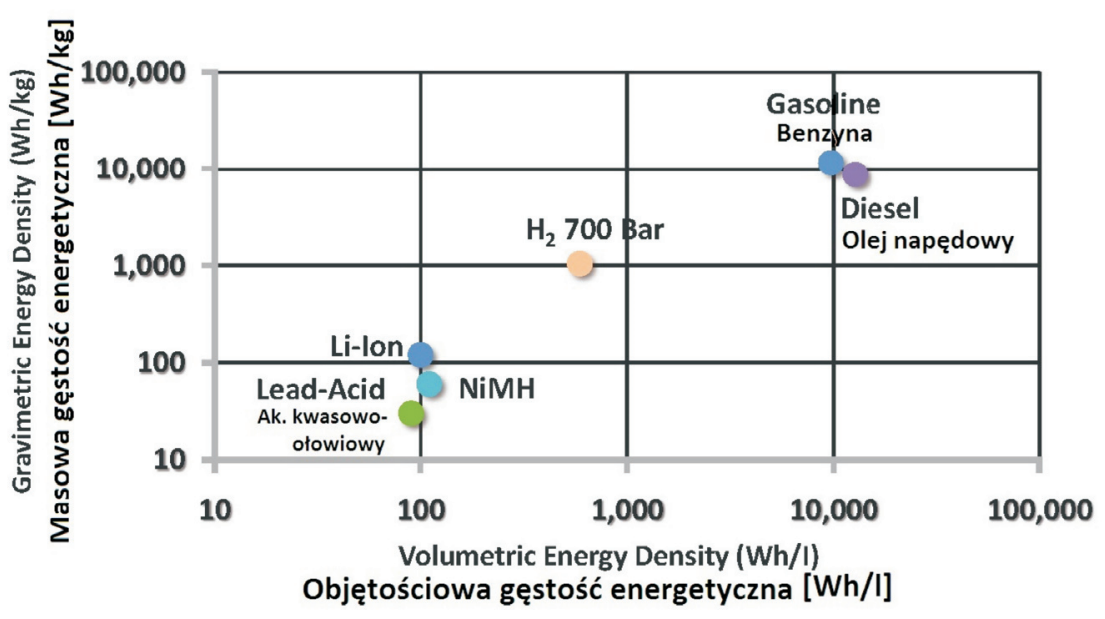

Fig. 3. Energy density of automotive fuels [17]

Rys. 3. Gęstość energetyczna wybranych paliw i źródet energii [17]

\section{Koszty energii}

Z uwagi na podatki i inne obciążenia fiskalne związane zarówno z napędem elektrycznym, jak i klasycznym, koszt eksploatacji przez użytkownika jest niższy dla pojazdów z napędem elektrycznym. Jeśli powyższe opłaty nie byłyby brane pod uwagę, koszt eksploatacji pojazdów elektrycznych w cyklu miejskim byłby wyższy.

Ceny pojazdów elektrycznych w średniookresowej perspektywie czasowej będą wciąż przewyższać poziom, który są w stanie zaakceptować zainteresowani nabywcy. W dalszej perspektywie zakłada się, że masowo produkowane samochody elektryczne kosztować będą o $6000 €$ więcej niż porównywalne pojazdy konwencjonalne [5]. Aktualnie jednak ceny dostępnych na rynku samochodów osobowych z napędem elektrycznym są około dwukrotnie wyższe w stosunku do porównywalnych samochodów z napędem konwencjonalnym.

Jakie są oczekiwania nabywców pojazdów z napędem elektrycznym?

1. Ceny zakupu samochodów elektrycznych będą w najbliższym czasie wciąż przewyższać akceptowalny przez klientów poziom. Aktualnie ceny samochodów elektrycznych są dwukrotnie wyższe niż ceny samochodów konwencjonalnych.

2. Koszt eksploatacji związany z zakupem energii jest dla pojazdów elektrycznych, z uwagi na obowiązujące podatki i inne opłaty, niższy od kosztu eksploatacji pojazdów z silnikami ZS.

3. W porównaniu do pojazdów z napędem konwencjonalnym aktualnie dostępne na rynku pojazdy elektryczne mają mniejszy zasięg, który dodatkowo jest bardzo uzależniony od temperatury zewnętrznej. Zakłada się, że niedogodność ta nie zostanie w najbliższym czasie przezwyciężona.

4. Dostępność ładowania

Lokalizacja w pobliżu parkingów samochodowych gniazd umożliwiających ładowanie akumulatorów jest czynnikiem niezbędnym w codziennej eksploatacji pojazdów z napędem elektrycznym. Proces ładowania akumulatorów wymaga dodatkowych czynności manipulacyjnych (podłączenie i rozłączenie złącza łądowania).

5. Efekt środowiskowy i wymagania energetyczne

Jeśli samochody elektryczne są eksploatowane w krajach korzystających Z energii odnawialnej (np. Austria), możliwe jest zredukowanie zarówno zużycia energii, jak i emisji gazów cieplarnianych w tym kraju. Rozpatrując sytuację Unii Europejskiej jako całości, płynące z powyższego korzyści są trudne do zaobserwowania. W krajach, w których tylko niewielka część energii pochodzi ze źródeł odnawialnych, w których przeważają niskie średnie temperatury powietrza, a przemieszczanie odbywa się przy średnich prędkościach głównie na dalekich dystansach 
for electric power and hydrogen [2]. But infrastructure also means service facilities such as workshops, testing centres and breakdown assistance with trained staff as well as additional parking spaces as electric cars will often be the second or third vehicle of their owners.

There can be no doubt that infrastructure will play a vital role in the introduction of future drive systems, because consumers are used to finding a filling station at a short distance and at any time. At these filling stations, consumers cannot only get fuels but are offered an ever widening range of services: They can buy food, beverages or snacks, perform banking and postal transactions or have their cars washed, minor repairs made, etc. In Germany, for example, around 15,000 filling stations provide such services, and approximately 2,800 providers of such services exist in Austria.

All new energy stations will have to measure up not only to this convenience standard, but also to the time required for refilling or charging. Also bear in mind that building the new infrastructure will take decades. Because of the existing vehicle fleet, it will have to be built in parallel to the currently available infrastructure.

I would now like to show you a comparison of the infrastructure costs of different sources of energy.

\subsection{Filling stations for liquid and gaseous fuels}

Fuel additives in small percentages (i.e. up to approximately $10 \%$ biogenic fuels) will give rise to relatively few problems in terms of infrastructure and costs, although the mineral oils industry insists that all costs for the reconstruction of filling stations will be passed on to consumers, and that new fuels like E10 would have to be sold at higher prices. The next step, offering pure biofuels or fuels with a high content of biogenic substances with up to $85 \%$ ethanol added to gasoline requires additional fuel infrastructures and thus leads to higher costs for consumers. Overall, it can be assumed that costs for future liquid fuels will remain at relatively reasonable levels.

The situation appears less favourable for gaseous fuels. For decades, efforts have been made to build up a satisfactory infrastructure network. However, this goal has still not been reached, although considerable government subsidies have been granted in the form of lower taxes on fuels for a long time. Once again, car manufacturers, energy companies and traffic associations recently launched another initiative under the lead of the German Energy Agency in order to facilitate progress. [6]. But at the end of the day, consumers can be persuaded to buy gas-driven cars only through state subsidies, as experience has shown that liquid fuels are better suited for ensuring mobility.

\subsection{Filling stations for electric energy (Battery-Electric Cars)}

Let me first describe the unproblematic aspect: there is enough electric power to supply the expected number of electric vehicles. As battery-electric propulsion systems would preferably be used in small vehicles with short ranges, it can be assumed [7] that approx. $5 \mathrm{kWh}$ power would be consumed for a daily driving distance of $30 \mathrm{~km}$. In principle, this energy can be obtained from the existing public (cykle pozamiejskie) pojazdy z silnikami o ZS daja więcej korzyści - mniejsze zużycie energii i/lub mniejszą emisję gazów cieplarnianych. Jeśli weźmie się pod uwagę gęstość energetyczną różnych źródeł, można zauważyc znaczne różnice (rys. 3).

\section{Porównanie rozwoju infrastruktury}

Przez infrastrukturę w rozpatrywanym kontekście rozumie się przede wszystkim dostępność stacji umożliwiających uzupełnienie energii, tj. stacji paliw płynnych i gazowych (CNG, LPG, wodór) oraz stacji elektrycznych [2]. Infrastruktura wiąże się ponadto $\mathrm{z}$ dostępnością wszelkich udogodnień serwisowych, takich jak warsztaty, stacje diagnostyczne, doraźna pomoc techniczna świadczona w nagłych wypadkach, czy też dodatkowe miejsca parkingowe dla pojazdów elektrycznych, będących często drugim lub trzecim samochodem właściciela.

Nie ulega więc wątpliwości, że infrastruktura odgrywa istotną rolę we wprowadzaniu przyszłościowych systemów, pozwalając konsumentom na szybkie znalezienie znajdujących się w pobliżu stacji uzupełniających energię. W tego typu stacjach, poza oczywistym uzupełnieniem paliwa, oferuje się ponadto szeroki wachlarz usług dodatkowych, takich jak zakup jedzenia, napojów lub przekąsek, wykonanie transakcji bankowych i pocztowych, czy też umycie samochodu, lub wykonanie drobnych jego napraw itp. Dla przykładu, w Niemczech funkcjonuje około 15000 stacji świadczących wymienione usługi, w Austrii jest ich około 2800.

Wszystkie stacje zasilania nowymi rodzajami energii muszą zapewnić nie tylko udogodnienia dostępne w konwencjonalnych stacjach paliw, ale również odpowiednio szybki proces uzupełnienia energii. Należy również pamiętać o tym, że budowa nowej infrastruktury zajmuje dekady. Jej tworzenie, z uwagi na aktualnie użytkowane pojazdy, powinno odbywać się równolegle do infrastruktury już istniejącej. W dalszej części artykułu przedstawiono porównanie kosztów infrastruktury dla różnych źródeł energii.

\subsection{Stacje tankowania paliw płynnych i gazowych}

Stosowanie biokomponentów paliwowych w niewielkiej ilości (tj. do $10 \%$ ) powoduje pojawienie się raczej niewielu problemów związanych z infrastrukturą i kosztami. Przemysł naftowy uważa, że wszelkie koszty przystosowania stacji tankowania do takich paliw muszą ponieść konsumenci przez sprzedaż nowych paliw, jak np. E10 po odpowiednio wyższych cenach. Oferowanie czystych biopaliw lub paliw z dużą zawartością biokomponentów (np. do $85 \%$ etanolu w benzynie) wymaga dodatkowej infrastruktury paliwowej, co również prowadzi do poniesienia przez konsumentów wyższych kosztów. Stwierdzić można jednak, że koszty przyszłych paliw płynnych pozostaną na relatywnie umiarkowanym poziomie.

Mniej korzystnie prezentuje się w Unii Europejskiej sytuacja paliw gazowych. Przez dekady poczyniono wiele starań prowadzących do budowy niezbędnej infrastruktury. Niemniej jednak, pomimo znaczących dotacji rządowych w postaci mniejszych podatków, cel ten nie został osiągnięty. W ostatnim czasie producenci pojazdów, przedsiębiorstwa $\mathrm{z}$ branży 
grid provided that a sufficient number of easily accessible plugs are available in parking lots, multi-storey parking garages, etc.

With proper logistic control of the charging process to ensure charging of the batteries, the existing low-voltage grid could be used without expanding its capacity. With a market penetration rate of 500 vehicles per 1,000 inhabitants, power consumption in Austria would rise by only approx. $12 \%$. The problems are in the details, such as dirty plugs and sockets, incomplete international standardization regarding, for example, the position of plugs and cables in the vehicle (front, rear end, or lateral). A sufficient number of parking spaces for battery charging is inconceivable in cities and towns.

But the crucial problem seems to be the time required for charging: with a regular plug for a $230 \mathrm{~V}, 16$ A electric current and a power of some $3.7 \mathrm{~kW}$, it takes about eight hours to charge a $30 \mathrm{kWh}$ vehicle battery. A plug for three-phase alternating current with up to $63 \mathrm{~A}(44 \mathrm{~kW})$ requires only approximately 45 minutes for charging. With a direct current voltage system in which the transformer technology is integrated into the charging unit, charging of several hundred $\mathrm{kW}$ is possible. In this way an electric car could be charged within a few minutes if this would not put too much strain on the batteries: the high losses in the fuel cells would cause temperatures to rise which would, in turn, negatively affect chemical processes [8].

Whereas electricity suppliers would like to control the scheduling for the long charging times, this does not necessarily correspond to consumers' wishes. Given the long charging times, battery-electric vehicles are unsuitable for long-distance driving unless they are equipped with strong range extenders.

The option of inductive charging is currently being studied, but many detailed questions have yet to be clarified. Some companies such as, IAV [9], Siemens [8] and others are making intensive efforts in this area. Battery-exchange systems are not considered as a viable solution for a number of reasons, including problems associated with the required standardization.

\subsection{Filling stations for hydrogen}

As it is generally believed that primarily larger vehicles would be equipped with fuel cells for driving over longer distances, the question of hydrogen infrastructure constitutes a particular problem. Island solutions, such as those conceived for starting battery-electric vehicles, could not be considered as a realistic option. The "hen or egg" dilemma appears particularly grave in this context. Daimler [10] points out that a two-pronged approach would be needed: i.e. simultaneous development of vehicles and filling stations. Only then will the fuel cell and hydrogen technologies meet with the approval of customers and the general public.

Linde AG presented its model project of a circular highway through Germany with a hydrogen infrastructure [11]. This project marks the beginning of the

establishment of a hydrogen infrastructure for German traffic. Such a circular highway would connect major conur- energetycznej oraz stowarzyszenia zajmujące się kongestią próbują pod przewodnictwem Niemieckiej Agencji Energetyki wprowadzać kolejne inicjatywy pozwalające na dokonanie postępu w omawianej dziedzinie [6]. Jednak w ostatecznym rozrachunku konsumenci mogą zostać przekonani do kupna pojazdów zasilanych gazem jedynie dzięki dotacjom, bo jak pokazało doświadczenie paliwa ciekłe są lepiej przystosowane do niezawodnego spełnienia potrzeb transportowych.

\subsection{Stacje ladowania pojazdów $z$ napędem elektrycznym}

Przede wszystkim należy zdać sobie sprawę z jednej kwestii - energia elektryczna jest dostępna w ilości umożliwiającej zaspokojenie potrzeb spodziewanej liczby pojazdów z napędem elektrycznym. Przy założeniu zastosowania napędów elektrycznych w małych pojazdach pokonujących krótkie dystanse stwierdzono [7], że dziennie na pokonanie dystansu $30 \mathrm{~km}$ potrzeba około $5 \mathrm{kWh}$ energii. Energia ta mogłaby być uzyskana $\mathrm{z}$ istniejącej publicznej sieci elektrycznej dzięki instalacji wystarczającej liczby gniazd na parkingach, wielopoziomowych garażach itp.

Przy właściwej kontroli procesu ładowania akumulatorów istniejąca niskonapięciowa sieć mogłaby być użytkowana bez większych zmian. Przy 500 pojazdach na 1000 obywateli, biorąc pod uwagę przewidywania austriackiego rynku, zakłada się, że zużycie energii wzrosłoby jedynie o 12 \%. Problem tkwi jednak w szczegółach dotyczących np. gniazd i wtyczek, w obszarze czego brak jest jednolitego międzynarodowego standardu uwzględniającego choćby pozycję wtyczki i przewodów w pojeździe (przód, tył, bok pojazdu). Również zapewnienie w miastach odpowiedniej liczby parkingów ze stacjami ładowania wydaje się trudne do zrealizowania.

Innym istotnym problemem jest czas potrzebny do pełnego naładowania akumulatorów. Przy standardowym złączu $230 \mathrm{~V}$, natężeniu prądu $16 \mathrm{~A}$ i mocy ok. $3,7 \mathrm{~kW}$ uzupełnienie energii w ilości ok. 30 kWh zajmuje około 8 godzin. Wykorzystanie prądu trójfazowego o natężeniu $63 \mathrm{~A}$ i mocy $44 \mathrm{~kW}$ pozwala na skrócenie tego czasu do około 45 minut. Z kolei użycie układu z prądem stałym, wykorzystującego technologię transformatorową zintegrowaną w jednostce ładującej umożliwia ładowanie mocą wynoszącą nawet kilkaset kW. W tym przypadku pojazd elektryczny mógłby być ładowany w przeciągu kilku minut. Warunkiem tego jest zachowanie optymalnego poziomu obciążenia akumulatorów - wysokie straty w ogniwach mogą powodować wzrost temperatury, co mogłoby mieć negatywny skutek na chemiczne procesy zachodzące w akumulatorach [8].

Dostawcy energii chcieliby móc planować zapotrzebowanie na energię elektryczną, dlatego preferują wolne ładowanie, co nie do końca jest zgodne z wymaganiami konsumentów. Ponadto technologia powolnego ładowania baterii pojazdów elektrycznych utrudnia pokonywanie długich tras, chyba że będą one wyposażone w specjalne urządzenia wydłużające możliwy do pokonania na jednym ładowaniu dystans.

Aktualnie jest rozwujane ładowanie indukcyjne, które jest rozwiązaniem alternatywnym. Intensywne prace w tej 
bations and hydrogen technology leaders, such as passenger car manufacturers. Approximately 35 hydrogen filling stations would be installed at intervals of some $50 \mathrm{~km}$ along the entire length of the highway totalling approximately $1,800 \mathrm{~km}$. The investment required for this project would amount to about 30 million Euro. The most cost-effective approach would consist of supplying liquid hydrogen to the planned filling stations from lorry tank trailers. Both the uses of pipelines and/or on-site production of liquid hydrogen would be far more costly.

It is difficult to understand how such an infrastructure could compete with the 15,000 filling stations for liquid fuels existing in Germany unless the state made massive interventions. The costs for establishing a Europe-wide infrastructure for supplying liquid hydrogen to 41.2 million vehicles at 18,000 filling stations by 2030 are estimated to be 18.5 billion euro [12].

\subsection{Cost comparison of the different infrastructures}

A comprehensive study [12] on all issues associated with alternative propulsion systems also contains a detailed comparison of costs. In an optimistic scenario it was assumed that the prices of fuel cell systems will go down by $90 \%$ by 2020 , those for battery-electric systems by $80 \%$ and those for hydrogen by $70 \%$ by the year 2025 as a result of volume effects and technological progress. With regard to internal combustion engines, it is expected that fuel consumption can be lowered by $30 \%$ whereas costs will remain at the same level as a result of hybridization and lightweight design. Tables 5 and 6 give a survey of the situation in the years 2020 and 2050:

As is shown by Table 5, the infrastructure cost for battery-electric and fuel-cell vehicles will exceed the costs for gasoline and diesel infrastructure by a factor of approximately 5 by 2020 .

Permit me to make some additional remarks concerning these two tables. [3] is based on the assumption that $50 \%$ of these vehicles will be charged at home at a price of 200 to 400 euro per charging station and the other $50 \%$ at public charging stations, where the costs are estimated at 10,000 euro for two cars. This would correspond to 1,500 to 2,500 euro per car. Opinions are divided concerning the costs of the electric charging infrastructure. [12] assumes that 25,000 euro would go into the production, installation and the grid connection of a power charging station for passenger cars.

With regard to the costs of hydrogen infrastructure [10] assumes $5 \%$ of the total costs of fuel-cell vehicles, i.e. 1,000 to 2,000 euro per car. The initial investment has been calculated at 3 billion euro, which includes hydrogen production, distribution and selling to final consumers. According to [12], the construction of a hydrogen infrastructure covering $25 \%$ of the market would cost 3 billion euro in the first year and 2 to 3 billion euro in subsequent years. [12] estimates that a large-scale roll-out of a hydrogen infrastructure in Europe over a 40 year period would require investments totalling 100 billion euro. In the opinion of [12], the risks involved in the construction of such a hydrogen infrastructure would be so high that no single company could assume them; hence the dziedzinie są obecnie prowadzone przez firmy IAV [9], Siemens [8] i inne. $Z$ kolei ze względu na wiele przyczyn związanych np. z ujednoliceniem standardów, układy opierające się na wymianie akumulatorów nie są uważane za rozwiązanie, które może być powszechnie stosowane.

\subsection{Stacje tankowania wodoru}

Jak powszechnie wiadomo, zastosowanie w pojazdach ogniw paliwowych pozwala na zwiększenie ich zasięgu. Podstawowym problemem jest jednak brak odpowiedniej infrastruktury umożliwiającej tankowanie wodoru. Daimler [10] zwraca uwagę na konieczność dwupłaszczyznowego podejścia, tj. przy jednoczesnym rozwoju pojazdów konieczny jest rozwój stacji tankowania paliwa. Tylko wtedy technologie ogniw paliwowych i wodoru spotkają się z aprobatą użytkowników i opinii publicznej.

W ostatnim czasie firma Linde AG zaprezentowała projekt infrastruktury wodorowej zbudowanej na biegnącej wokół Niemiec autostradzie [11]. Jest to niewątpliwie początek tworzenia tego typu infrastruktury w Niemczech. W planowanym rozwiązaniu przewiduje się zbudowanie infrastruktury wzdłuż autostrady łączącej główne aglomeracje $\mathrm{z}$ liderami $\mathrm{w}$ dziedzinie wodoru, takimi jak np. producenci samochodów osobowych. W tym celu zamierza się zbudować około 35 stacji tankowania rozmieszczonych co $50 \mathrm{~km}$, na łącznej długości $1800 \mathrm{~km}$. Koszt inwestycji wynosi około 30 milionów euro. Najbardziej opłacalnym sposobem dostarczania ciekłego wodoru do stacji napełniania byłoby wykorzystanie pojazdów z cysternami. Znacznie droższym rozwiązaniem byłoby użycie rurociągów i/lub produkcja ciekłego wodoru bezpośrednio przy stacji.

Bez znaczącej interwencji władz państwowych trudno sobie jednak wyobrazić istnienie i konkurowanie tego typu stacji z aktualnie działającymi w Niemczech 15000 stacjami tankowania paliw płynnych. Koszt stworzenia ogólnoeuropejskiej sieci umożliwiającej dostarczanie wodoru na potrzeby 41,2 mln samochodów przy założeniu powstania 18000 stacji do 2030 roku wynosi około 18,5 mld euro [12].

\subsection{Porównanie kosztów infrastruktury \\ dla poszczególnych paliw i napędów}

Obszerne studium zagadnień związanych z alternatywnymi napędami zawarte w publikacji [12] uwzględnia między innymi szczegółowe porównanie kosztów. W optymistycznym scenariuszu zakłada się, że ceny układów z ogniwami paliwowymi zmaleją o $90 \%$ do 2020 roku, w odniesieniu do akumulatorowych układów elektrycznych o $80 \%$, w przypadku wodoru o $75 \%$ do 2025 roku - zmniejszenie powyższych kosztów nastąpi jako skutek postępu technicznego. W odniesieniu do silników spalinowych przewiduje się, że zużycie paliwa spadnie o $30 \%$, przy jednoczesnym utrzymaniu podobnych kosztów eksploatacji - przyczyną w tym przypadku będzie hybrydyzacja i zmniejszanie masy własnej pojazdów. W tabelach 5 i 6 przedstawiono porównanie kosztów dla wybranych paliw i napędów odpowiednio dla lat 2020 i 2050 .

Zgodnie $\mathrm{z}$ danymi zawartymi $\mathrm{w}$ tabeli 5 koszt infrastruktury dla pojazdów $\mathrm{z}$ akumulatorowym napędem elektrycznym (BEV) oraz pojazdów z napędem elektrycznym wyko- 
risks would have to be shared with the general public. The chance that the company that initially establishes a hydrogen infrastructure would benefit from the early mover effect is considered slim.

\subsection{Summaryof the chapter 4}

- The infrastructure (filling stations, service centres with trained staff) will, to a considerable extent, influence the introduction of alternative propulsion systems.

- Drive systems not requiring a new infrastructure or requiring only small modifications to the existing infrastructure offer major advantages because of the wide availability of the existing infrastructure on the one hand and the avoidance of investments in new infrastructure on the other, which would, in the final analysis, have to be paid for by all users of new propulsion systems.

- From the perspective of infrastructure, internal combustion engines using liquid fuels offer many advantages. Even new liquid fuels or new additives do not give rise to problems with infrastructure.

- The massive investments required for the building of electric charging stations will be a major obstacle to the introduction of electro-mobility. In addition, the charging-parking space dilemma must be considered as many electric cars will be their owners' second cars, and the extremely long charging time constitutes yet another obstacle.

Table 5. Purchase prices, cost of maintenance, fuels and infrastructure of fuel-cell electric vehicles (FCEV), battery-electric vehicles (BEV), plug-in-hybrid vehicles (PHEV), vehicles with gasoline engines (ICE - gasoline) and vehicles with diesel engines (ICE - diesel) for the year 2020

Tabela 5. Ceny zakupu, eksploatacji, paliw i infrastruktury pojazdów z napędem elektrycznym wykorzystujących ogniwa paliwowe (FCEV), pojazdów z akumulatorowym napędem elektrycznym (BEV), pojazdów hybrydowych typu ,plug-in” (PHEV), pojazdów z silnikami ZI (ICE-gasoline) i pojazdów z silnikami ZS (ICE - diesel) - rok 2020 [12]

EUR thousands/ tys. EUR

$$
\begin{aligned}
& \text { Ve } \\
& \text { Po } \\
& \hline \text { FCE } \\
& \text { BEV } \\
& \text { PH } \\
& \text { IC } \\
& \text { IC } \\
& \text { Pe } \\
& \hline \text { FC } \\
& \text { BEV } \\
& \text { PH } \\
& \text { IC } \\
& \text { IC } \\
& \text { Veh } \\
& \text { Poj } \\
& \hline \text { FC } \\
& \text { BEV } \\
& \text { PH } \\
& \text { IC } \\
& \text { IC }
\end{aligned}
$$

\begin{tabular}{|c|c|c|c|}
\hline $\begin{array}{l}\text { Vehicle/ } \\
\text { Pojazd }\end{array}$ & $\begin{array}{l}\text { Purhase price/ } \\
\text { Cena zakupu }\end{array}$ & $\begin{array}{c}\text { Maintenancel } \\
\text { Eksploatacja }\end{array}$ & \\
\hline FCEV & 20.0 & 2.8 & \\
\hline BEV & 16.9 & 2.3 & \\
\hline PHEV & 14.7 & 2.9 & \\
\hline ICE - gasoline & 11.3 & 3.0 & \\
\hline ICE - diesel & 11.3 & 3.0 & \\
\hline $\begin{array}{l}\text { Vehicle/ } \\
\text { Pojazd }\end{array}$ & $\begin{array}{l}\text { Purhase pricel } \\
\text { Cena zakupu }\end{array}$ & $\begin{array}{c}\text { Maintenance/ } \\
\text { Eksploatacja }\end{array}$ & \\
\hline FCEV & 30.9 & 4.5 & \\
\hline BEV & 28.9 & 3.7 & \\
\hline PHEV & 26.8 & 4.9 & \\
\hline ICE - gasoline & 21.4 & 5.5 & \\
\hline ICE - diesel & 21.9 & 5.7 & \\
\hline $\begin{array}{l}\text { Vehicle/ } \\
\text { Pojazd } \\
\end{array}$ & $\begin{array}{l}\text { Purhase pricel } \\
\text { Cena zakupu }\end{array}$ & $\begin{array}{c}\text { Maintenance/ } \\
\text { Eksploatacja }\end{array}$ & \\
\hline FCEV & 38.9 & 5.6 & \\
\hline BEV & 41.0 & 5.4 & \\
\hline PHEV & 37.0 & 6.7 & \\
\hline ICE - gasoline & 28.5 & 7.1 & \\
\hline ICE - diesel & 29.5 & 7.5 & \\
\hline
\end{tabular}

1 Includes production and distribution cost/ Włączając koszt produkcji i dystrybucji

2 Includes retail cost/ Włączając koszt detaliczny

NOTE: Assuming 15 years lifetime, annual driving distance of $12,000 \mathrm{~km}$, no tax (e.g., fuel excise, VAT)l

UWAGA: Przy założeniu 15 lat, rocznego dystansu 12,000 km, bez podatków (np. akcyza za paliwo, VAT)

3 Total Cost of Ownership/ Całkowity koszt posiadania rzystujących ogniwa paliwowe (FCEV) do 2020 roku będzie pięciokrotnie przekraczał koszty infrastruktury pojazdów z silnikami ZI (ICE - gasoline) i ZS (ICE - diesel). Analiza danych tabel 5 i 6 pozwala na wyciągnięcie dodatkowych wniosków. W pozycji [3] oparto się na założeniu, że $50 \%$ $\mathrm{z}$ opisywanych pojazdów będzie ładowanych z wykorzystaniem przydomowych stacji, których koszt wyniesie 200 - 400 euro; pozostałe $50 \%$ stanowić będą publiczne stacje ładowania, których szacowany koszt wynosił będzie 10000 euro za stanowisko umożliwiające jednoczesne ładowanie dwóch samochodów. Będzie to odpowiadać 1500 do 2500 euro za samochód. Odnośnie do kosztów infrastruktury ładowania opinie są podzielone. Na podstawie pracy [12] zakłada się, że dla samochodów osobowych produkcja oraz instalacja i podłączenie sieci elektrycznej wyniesie dla pojedynczej stacji ładowania około 25000 euro.

W odniesieniu do infrastruktury wodorowej zakłada się [10] jej koszt na poziomie $5 \%$ całkowitego kosztu wszystkich pojazdów z ogniwami paliwowymi, co odpowiada $1000-$ 2000 euro na 1 pojazd. Wstępne koszty inwestycji uwzględkoszt produkcji wodoru, dystrybucję i sprzedaż do docelowego klienta szacowane są na 3 mld euro. Zgodnie z [12] zbudowanie infrastruktury wodorowej pozwalającej na zaspokojenie potrzeb $25 \%$ rynku ocenia się na około $3 \mathrm{mld}$ euro w pierwszym roku i od 2 do 3 mld euro w latach kolejnych. Szacuje się ponadto, że dla Europy wprowadzenie na szeroką skalę wodorowej infrastruktury stanowić może na przestrzeni najbliższych 40 lat koszt 100 mld euro. Żadna prywatna firma nie byłaby w stanie ponieść tak wysokiego ryzyka związanego $\mathrm{z}$ utworzeniem infrastruktury wodorowej, ryzyko to musi być w związku z tym ponoszone publicznie.

\subsection{Podsumowanie rozdziału}

- Utworzenie działającej na szeroką skalę infrastruktury (stacje tankowania, centra serwisowe z wyszkolonym personelem) będzie miało istotny wpływ na wprowadzanie na rynek alternatywnych układów napędowych.

- Zastosowanie układów napędowych niewymagających utworzenia nowej infrastruktury, bądź też takich, które wymagają jedynie niewielkich jej modyfikacji łączy się z co najmniej dwoma zaletami: z jednej strony istniejąca infrastruktura jest łatwo dostępna, z drugiej - brak jest koniecz- 
Table 6. Purchase prices, cost of maintenance, fuels and infrastructure of fuel-cell electric vehicles (FCEV), battery-electric vehicles (BEV), plug-in-hybrid vehicles (PHEV), vehicles with gasoline engines (ICE - gasoline) and vehicles with diesel engines (ICE - diesel) for the year 2050

Tabela 6. Ceny zakupu, eksploatacji, paliw i infrastruktury pojazdów z napędem elektrycznym wykorzystujacych ogniwa paliwowe (FCEV), pojazdów z akumulatorowym napędem elektrycznym (BEV), pojazdów hybrydowych typu ,plug-in” (PHEV), pojazdów z silnikami ZI (ICE-gasoline) i pojazdów z silnikami ZS (ICE-diesel) - rok 2050 [12]

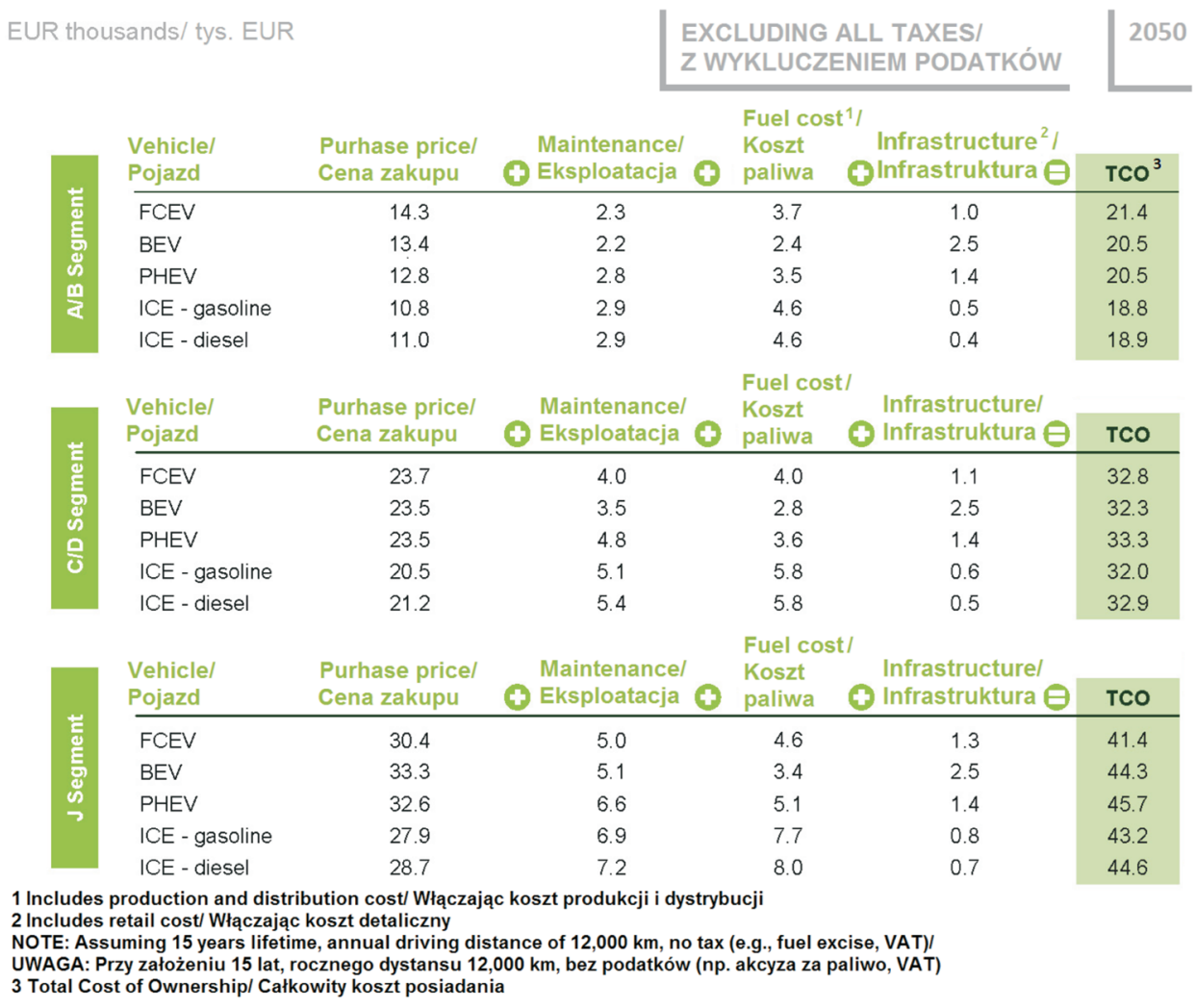

- Establishing a hydrogen infrastructure costs a lot of money. This problem will further delay the introduction of fuel-cell propulsion systems.

\section{Possible solutions}

From what I have stated previously, it can be concluded that liquid fuels have the highest potential for assuring mobility in the future. It can even be said that in the event of scarcity, these fuels should be reserved for mobility, as it is easier to substitute them in all other areas. Gas, solar energy, geothermal energy or biomass can be used for heating purposes. The supply of electric power can be ensured with a mix of coal, nuclear energy, solar energy, hydroelectric power or wind energy [15].

Amongst fuels for mobility, GTL (gas-to-liquids) will play a vital role. GTL will not only contribute to the diversification of energy supply but also to the reduction of emissions caused by road traffic. GTL fuels are of vital importance either as pure fuels or as additives to conventional diesel fuels [13].

The quality of conventional liquid fuels has been significantly improved over the past few years thanks to the introduction of sulphur-free fuels with lower aromatic contents as well as low-ash engine oils. These positive developments are, however, jeopardized [14] by the obligation to add bio- ności poniesienia kosztów budowy nowej infrastruktury przez użytkowników alternatywnych układów napędowych.

- Z perspektywy istniejącej infrastruktury silniki spalinowe zasilane paliwami płynnymi mają wiele zalet. Nowe paliwa płynne lub też nowe komponenty paliw konwencjonalnych nie generują problemu związanego $\mathrm{z}$ dostosowaniem do nich wykorzystywanej infrastruktury.

- Znaczące inwestycje wymagane przy budowie stacji ładowania pojazdów elektrycznych stanowić będą podstawową przeszkodę $\mathrm{w}$ rozwoju tego typu układów. Dodatkowy problem związany będzie z koniecznością zapewnienia przestrzeni parkingowej dla pojazdów z napędami elektrycznymi - dla wielu użytkowników samochody te stanowić będą drugi samochód. Innym ograniczeniem jest wciąż długi czas ładowania akumulatorów elektrycznych.

- Szacowany koszt budowy infrastruktury wodorowej jest znaczny. Problem ten będzie przyczyną opóźnienia upowszechnienia układów napędowych wykorzystujących ogniwa paliwowe.

\section{Prawdopodobne rozwiązania}

Na podstawie przeprowadzonej w poprzednich rozdziałach analizy stwierdzić można, że paliwa płynne mają największy potencjał w zaspokojeniu przyszłościowych potrzeb transportowych. Można ponadto stwierdzić, że w przypadku wyczerpywania się zasobów paliw konwencjonalnych część z nich powinna być zarezerwowana przede wszystkim na cele transportowe - podejście takie wynika z łatwości wykorzystania zamienników paliw konwencjonalnych w innych obszarach techniki. Gaz ziemny, energia słoneczna, energia geotermalna lub biomasa powinny być wykorzystywane głownie do celów grzewczych. Zaopatrzenie $\mathrm{w}$ energię elektryczną powinno być zapewnione jako powiązanie energetyki węglowej z nuklearną, słoneczną, wodną lub wiatrową [15].

W produkcji paliw silnikowych coraz większe znaczenie będzie odgrywać technologia GTL (gas to liquid). Metoda ta nie tylko przyczynia się do dywersyfikacji źródeł dostarczanej energii, ale również do redukcji emisji związków szkodliwych powodowanych przez motoryzację. Paliwa 
fuels, especially fatty acid methyl esters (FAME, biodiesel) to conventional fuels.

Numerous technologies are available for the production of synthetic hydrocarbons. Which technology makes the best sense depends on the available process energy. wytwarzane w technologiach GTL mogą być używane jako samoistne paliwa lub jako dodatek do konwencjonalnego oleju napędowego [13].

Jakość paliw konwencjonalnych uległa w ostatnim czasie znaczącej poprawie, co było skutkiem zarówno wprowadzenia paliw bezsiarkowych i o zmniejszonym udziale składników aromatycznych, jak również niskopopiołowych olejów silnikowych. Ten pozytywny trend jest jednak zagrożony [14] obligatoryjną koniecznością stosowania w paliwach konwencjonalnych biokomponentów, w szczególności takich jak estry metylowe kwasów thuszczowych (FAME).

Do produkcji syntetycznych węglowodorów wykorzystuje się aktualnie różne technologie. O tym, jakie rozwiązanie powinno być zastosowane decyduje rodzaj dostępnej energii. Jeśli dostępna jest energia elektryczna wytwarzana

If electric power generated from wind or solar energy is available, hydrogen $\mathrm{H}_{2}$ can be produced through electrolysis. This hydrogen may then be used for converting $\mathrm{CO}_{2}$ into $\mathrm{CO}$ by means of the water-gas reaction $\left(\mathrm{CO}_{2}+\mathrm{H}_{2} \rightarrow \mathrm{CO}+\right.$ $\mathrm{H}_{2} \mathrm{O}$ ). $\mathrm{CO}$ can subsequently be hydrogenated using various catalytic processes (Fischer-Tropsch) or methanol (MtG, MtSynfuel) in order to obtain carbons.

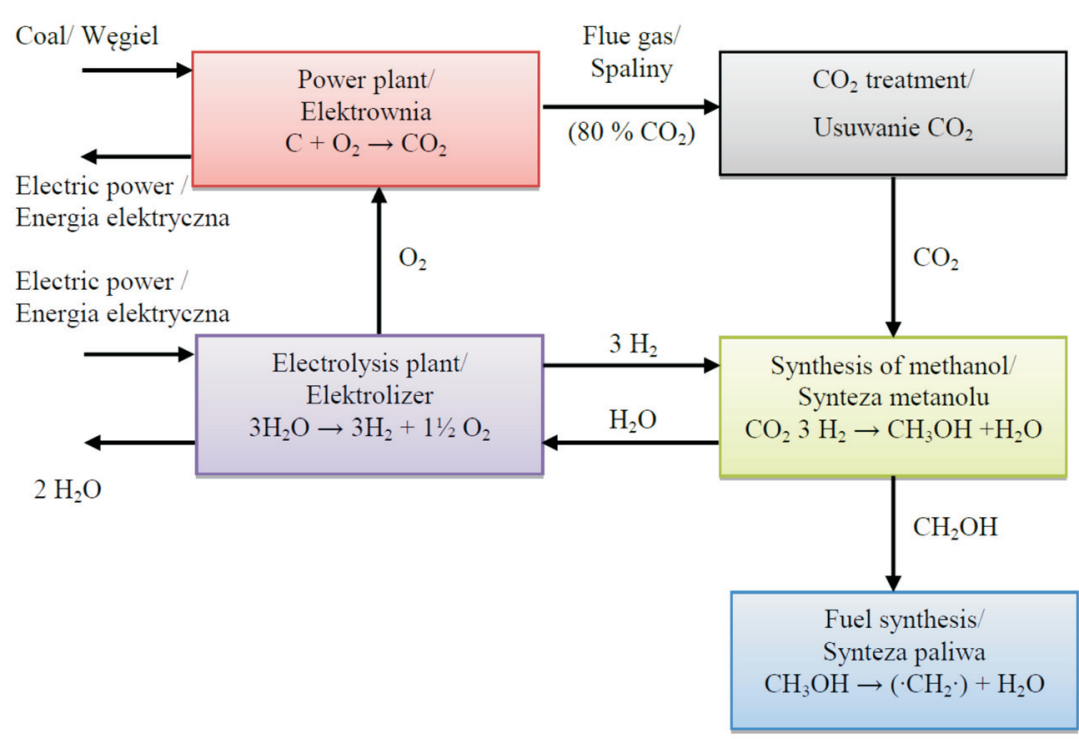

Fig. 5. Chemical reaction in CWtL-synthesis - reduction of $\mathrm{CO}_{2}$ from power plants to methanol and fuel synthesis in accordance with the MtG-MtSynfuel process [15]

Rys. 5. Reakcje chemiczne syntezy $\mathrm{CWtL}$ - redukcja $\mathrm{CO}_{2}$ z elektrowni do metanolu oraz synteza paliwa w procesie MtG-MtSynfuel [15] $\mathrm{z}$ energii wiatru lub energii słonecznej, wodór $\mathrm{H}_{2}$ może być produkowany na drodze elektrolizy. Tak wyprodukowany wodór może być następnie użyty do konwersji $\mathrm{CO}_{2}$ w $\mathrm{CO}$ $\left(\mathrm{CO}_{2}+\mathrm{H}_{2} \rightarrow \mathrm{CO}+\mathrm{H}_{2} \mathrm{O}\right)$. Powstały CO może być następnie uwodorniony przy użyciu procesów katalitycznych typu synteza Fischera-Tropscha lub z wykorzystaniem metanolu (MtG,

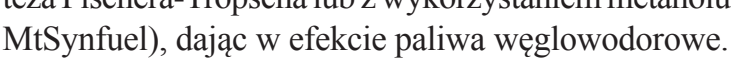

W ostatnim czasie Maus w Motortechnische Zeitschrift (MTZ) [15] zaprezentował procedurę za pomocą której $\mathrm{CO}_{2}$ nie musi być magazynowany. Zasadę realizacji procesu upłynnienia $\mathrm{CO}_{2}$ przy udziale wody (CWtL) przedstawiono na rys. 4 . Na rysunku 5 zamieszczono przebieg odpowiedzialnych za proces reakcji chemicznych. Wydaje się, że zachodząca w procesie transformacja energii elektrycznej na energię chemiczną ma wyższą wydajność niż tradycyjny odwrotny proces. Nie ulega zatem wątpliwości, że w przyszłości dostępnych będzie wiele technologii umożliwiających produkcję paliw płynnych.

\section{Wnioski i prognozy na przyszlość}

Transport oparty wyłącznie na zasilanym akumulatorowo napędzie 
Recently Maus presented a procedure in Motortechnische Zeitschrift (MTZ) [15] with which, $\mathrm{CO}_{2}$ does not need to be stored. The principle of a carbon dioxide and water-to-liquid process (CWtL) is illustrated in Fig. 4 and the chemical processes taking place are shown in Fig. 5. This transformation of electrical energy into chemical energy seems to have a higher efficiency than the usual, inverted process. At any rate, in the future, there will be many options for the production of liquid fuels.

\section{Conclusions and outlook}

Purely battery-electric mobility will be applied in the future only in specific areas. Fuel-cell vehicles will hardly be used because of the extreme infrastructure investment costs. In contrast, liquid fuels will ensure the future of mobility. In this scenario, energy such as solar or wind energy will be generated without $\mathrm{CO}_{2}$ emissions. The complete infrastructure is available world-wide, so are the drive units. Why should we leave this path? For large marine vessels, methane drives could be a bridge technology for the future.

The answers to the question "Future Mobility without Internal Combustion Engines and Fuels?" are "no" in both cases. For many decades to come, and in the foreseeable future, internal combustion engines - in many cases with electric motors - will be with us, just like the liquid fuels they require. The importance of crude oil will decline, as these fuels will be increasingly produced on a synthetic basis without $\mathrm{CO}_{2}$ emissions. elektrycznym będzie w przyszłości wykorzystywany jedynie w wybranych obszarach. Pojazdy wykorzystujące ogniwa paliwowe nigdy nie osiągną większej popularności ze względu na wysokie koszty budowy niezbędnej infrastruktury. Paliwa płynne także w przyszłości będą podstawowym nośnikiem energii wykorzystywanym w środkach transportu. Do ich produkcji w coraz większym stopniu wykorzystywane będą jednak technologie o niskiej bądź zerowej emisji $\mathrm{CO}_{2}$, jak na przykład baterie słoneczne, czy fermy wiatrowe. Infrastruktura produkcji i dystrybucji paliw płynnych jest rozpowszechniona na całym świecie, podobnie jak jednostki napędowe zasilane paliwami płynnymi. Dlaczego więc porzucać sprawnie funkcjonujące rozwiązania? To dla dużych statków morskich zasilanie gazem ziemnym może stanowić rozwiązanie przejściowe dla przyszłych technologii.

Odpowiedź na pytanie „Czy transport w przyszłości odbywać się będzie bez silników spalinowych i paliw?" brzmi „nie” w obu przypadkach. Silniki spalinowe funkcjonują już przez wiele dekad i w dającej się przewidzieć przyszłości wciąż będą powszechnie stosowane, podobnie jak paliwa płynne potrzebne do ich zasilania. Znaczenie ropy naftowej będzie jednak powoli malało w miarę wzrostu skali produkcji paliw syntetycznych w procesach zapewniających małą emisję $\mathrm{CO}_{2}$.

\section{Bibliography/Literatura}

[1] Geringer B. et al.: Batterieelektrische Fahrzeuge in der Praxis - Kosten, Reichweite, Umwelt, Komfort. Publikation des Österreichischen Vereins für Kraftfahrzeugtechnik, Juni 2012.

[2] Lenz H.P.: Die Rolle der Infrastruktur für das Automobil der Zukunft, ATZ-Extra April 2011, s. 113-117.

[3] Wagner U. et al.: Ganzheitliche Bewertung alternativer Kraftstoffe und innovativer Fahrzeugantriebe. [Buchverf.] D. Naunin. Hybrid-Batterie- und Brennstoffzellen-Elektrofahrzeuge. Renningen: Expert Verlag, 2007. ISBN-10: 3-8169-2625-8.

[4] Althaus H. et al.: Vergleichende Ökobilanz individueller Mobilität: Elektromobilität versus konventionelle Mobilität mit Bio- und fossilen Treibstoffen. Dübendorf: EMPA, 2010.

[5] Tober W.: Zukünftige Mobilität - Elektromobilität als Lösung? Wien: TU Wien, Institut für Verbrennungskraftmaschinen und Kraftfahrzeugbau, 2010. Veröffentlicht durch den Österreichischen Verein für Kraftfahrzeugtechnik (ÖVK). B10032.

[6] www.automobilwoche.de, 22.12.2010

[7] Brauner G.: Elektrische Energieversorgung und Mobilität in Europa. 30. Internationales Wiener Motorensymposium 2009, VDI-Fortschritt-Berichte, Reihe 12, Nr. 697.

[8] SIEMENS: Pictures of the Future, Herbst 2010, S. 34-36.

[9] Nietsche W.: Induktive Aufladung. ATZ elektronik-Interview 22.02.2010. Blumenröder, E.: ATZ-Interview 07-08/2009.

[10] Daimler: Der Kraftstoff Wasserstoff. Wasserstoff-Tankstellen. Aufbau eines flächendeckenden Netzes. www.daimler.com/ dccom.

[11] Wolf J. et al.: Wasserstoff Infrastruktur. 24. Mai 2005. Linde AG.
[12] A portfolio of power-trains for Europe: a fact based analysis. The Role of Battery Electric Vehicles, Plug-in Hybrids and Fuel Cell Electric Vehicles. www.zereoemissionvehicles.eu, 8.11.2010.

[13] Warnecke W. et al.: GTL Kraftstoff in einem angepassten Fahrzeug - Untersuchung des vollen Emissionsminderungspotenzials. 31. Internationales Wiener Motorensymposium 2010, VDI Fortschritt-Berichte Nr. 716, 2010.

[14] Jacob E.: Dieselkraftstoffe im technologischen Übergang zum postfossilen Zeitalter. 33. Internationales Wiener Motorensymposium 2012, VDI Fortschritt-Berichte Nr. 749, 2010.

[15] Maus W. et al.: Nachhaltigkeit verfügbarer Kraftstoffe - eine Fiktion? MTZ 06/2012, S. 446-454.

[16] Peier O.: Alternative drive systems with a focus onelectric drive vehicle technology, ACVR, January 25, 2010.

[17] Grebe U.D.: GM's Voltec Propulsion System. Motor \& Umwelt 2009.

Univ. Prof. Dr. Hans Peter Lenz - Vienna University of Technology, President of the Austrian Society of Automotive Engineers.

Prof. dr Hans Peter Lenz - profesor (em.) na Uniwersytecie Technicznym w Wiedniu, przewodniczący Austriackiego Stowarzyszenia Inżynierów Motoryzacji.

e-mail: hans-peter.lenz@oevk.at 